\title{
非線形むだ時間システムの安定化法と動特性*
}

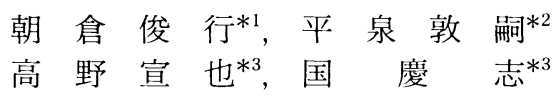

\section{Stabilizing Method for Nonlinear Time-Delay System and Its Dynamics}

\author{
Tosiyuki ASAKURA, Atsushi HIRAIZUMI, \\ Yosinari TAKANO and Qingzhi GUO
}

\begin{abstract}
This paper concerns a stabilizing method for nonlinear time-delay systems. (ienerally, hunting frequently occurs in a system with a time-delay, and is difficult to prevent. The Smith compensator is well known as a method for stabilizing such systems. However, it is fairly difficult to apply this method in practice because of both the existence of nonlinearity and the difficulty of modelling for a real system. In particular, the identified error between controlled object and controller causes instability of the system. In this research, to prevent hunting, a new stabilization method is proposed. This method can prevent hunting, and reduce the steady-state error to zero by parameter adjustment. First, the stability analysis of nonlinear time-delay system is clarified using the circle theorem. Second, in order to analyze the robustness of the new compensator, its robust stability condition is derived for such control systems with a dead time and a saturated-type nonlinearity, and the stability margins under the identified errors of time lag are evaluated. Third, the new compensator is directly represented by a $z$ transform, and its stabilization and dynamical characteristics are analyzed using the root locus method. From these studies, it is verified that the new stabilization method can be useful for general nonlinear time-delay control systems.
\end{abstract}

Key Words: Control Device, Deadtime, Hunting, Nonlinear System, Stabilization, Robust Stability, Root Locus

\section{1. 緒言}

プロセス制御において動特性の改善を妨げる問題点 の一つにむだ時間の存在がある。むだ時間を含むシス テムは無限次元システムであるため一般にその解析は 困難であり，特に非線形むだ時間システムで表現され る系においては，むだ時間による動作遅れのための発 振現象(ハンチング) が生じ, 安定な特性を得ることが 困難である。このような系の安定化法としてスミス補 償法(1) が知られているが, 系が線形でかつ制御対象の 厳密なシステム同定を必要とすることや, 外乱に対し て定常偏差が生じる等実用上多くの課題がある.

著者らは電空弁ポジショナのようなむだ時間と非線 形要素をもつシステムを対象として, スミス補償器と は別のより簡便で新しいむだ時間補償器を提案し た ${ }^{(2)}$. 本補償法はスミス補償器と異なり, 補償回路の 中に制御対象の伝達関数を含まず，かつ制御対象と補 償回路におけるむだ時間の同定誤差に対して強いロバ スト性をもつ.さらに定常偏差も零にできるという特

* 1995 年 8 月 22 日 Dynamics and Design Conference’ 95 に おいて講演, 原稿受付 1996 年 5 月 30 日.

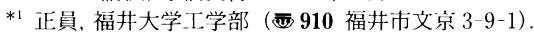

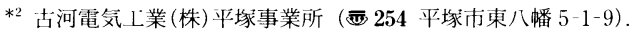

*3 学生員, 福井大学大学院.
徵を持つ、著者らはまず電空弁ポジショナの動的挙動 (特に発振現象の様態)およびその信号伝達手段である 空気圧管路モデルを定性的, 定量的に明らかにし た (3). 次に新しいむだ時間補償器に基づくディジタル 補償器を設計し，長い空気圧管路を含む電空弁ポジシ ヨナの安定化実験を行い, 本手法の有効性を確認し $た^{(4)}$.

本研究では, 新しいむだ時間補償器のはん化性抢よ び定性的な検討を行うため, 制御対象が 0 形および I 形からなる一般的な非線形むだ時間システムを考察の 対象とする。また提案するむだ時間補償器を含む系は 無限個の極をもつことから連続系における極および根 軌跡による解析は困難である。ささに本むだ時間補償 器は補償器の中にむだ時間要素を含むため, 一般にデ イジタル補償器を構成する必要がある。ここでは系を 離散化し, システムの極位置および特性根の挙動から 動的挙動およびロバスト安定解析を行い, 非線形要素 を含むむだ時間システムにおける本補償器の有効性を 確認する。

\section{2. 定位性プロセスの安定化}

本研究で提案するむだ時間補償器の有効性およびは ん用性を調べるため、一般的な非線形むだ時間システ 


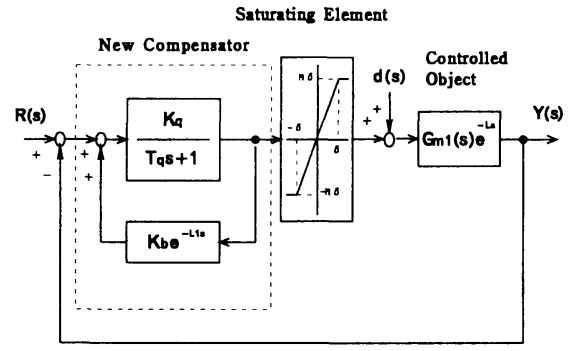

Fig. 1 Block diagram of control system with new time-delay compensator

ムを構成し, 周波数応答解析, ロバスト安定解析等か らその有効性を考察する。

$2 \cdot 1$ ブロック線図図1に新しいむだ時間補償 器を含む定位性プロセス ( 0 形)のブロック線図を示 す.ただしこの論文で示す記号は次のとおりである.

$K_{q}$ : 補償器の一次遅れのゲイン

$T_{q}$ : 補償器の一次遅れの時定数

$K_{b}$ : 補償器のフィードバックゲイン

$L_{1}$ : 補償器の同定されたむだ時間

$M:$ 非線形要素の線形係数

$e:$ 非線形要素への入力振幅

$\delta:$ 非線形要素の入力の飽和値

$K_{m}:$ 制御対象のゲイン

$T_{m}:$ 制御対象の時定数

$L:$ 制御対象のむだ時間

$d:$ 外乱要素

$R$ : 入力信号

$Y$ : 出力信号

新しいむだ時間補償器の伝達関数は図 1 より次式で 表される。

$$
D_{1}(s)=\frac{K_{q}}{1+T_{q} s-K_{q} K_{b} e^{-L 1 s}}
$$

本むだ時間補償器は二つの特徵をもつ。一つは補償 器の中に一次遅れのフィル夕を含むことである.もう 一つはスミス補償器と異なり, 補償器の中に制御対象 の伝達関数を含まず，むだ時間 $L_{1}$ のみが制御対象の むだ時間 $L に$ に近い值をとることを必要とすることで ある、本補償器により制御対象が電空弁ポジショナの ような飽和形非線形要素とむだ時間要素を含むシステ ムにおいて, 安定に動作させ得ることを明らかにし た. 本研究では, 新しいむだ時間補償器のはん化性お よび定性的な検討を行うため, 制御対象の伝達関数 $G_{m 1}(s)$ を次式のような 0 形とし解析を行う.

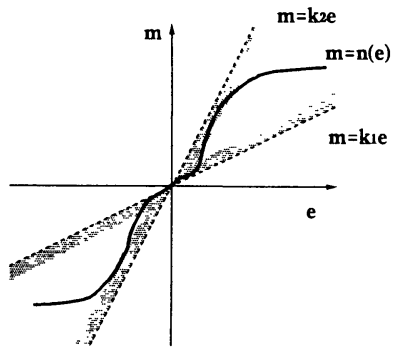

Fig. 2 Characteristics of nonlinear element

$$
G_{m 1}(s)=\frac{K_{m}}{T_{m} s+1}
$$

$2 \cdot 2$ 円板定理による安定判別 式(1)のむだ時 間補償器の有効性を確かめるため, ここでは, 実用上上 比較的適用の容易な円板定理 (5) を導入し, 図 1 の安定 判別を行う. 非線形要素の入出力関係は次式のように 表されるものとする。

$$
m=N(e)
$$

また図 2 のように非線形特性は第 1 象限と第 3 象限 にあり, かつ $m=k_{2} e$ と $m=k_{1} e$ の 2 直線で挟まれた 領域にあるとした場合, 非線形フィードバック制御系 が大域的漸近安定であるためには

$$
\operatorname{Re}\left[\frac{D_{1}(j \omega) G_{m 1}(j \omega)}{1+k_{1} D_{1}(j \omega) G_{m 1}(j \omega)}+\frac{1}{k_{2}-k_{1}}\right] \geqq 0
$$

を満足すればよい.

非線形要素が飽和形の場合,

$$
0 \leqq \frac{N(e)}{e} \leqq M
$$

となるから, 式(1), および(2)を用いて, 式(4)の 大域的漸近安定条件は次のように得られる。

$\left[K_{q} K_{m} \frac{a \sin (\omega L)-b \sin (\omega L)}{a^{2}+b^{2}}\right] \geqq-\frac{1}{M} \cdots \cdots(6)$ ただし，

$$
\begin{aligned}
a & =1-K_{q} K_{b} \cos \left(\omega L_{1}\right) \\
& -T_{m}\left\{T_{q} \omega+K_{q} K_{b} \sin \left(\omega L_{1}\right)\right\}, \\
b & =T_{m} \omega\left\{1-K_{q} K_{b} \cos \left(\omega L_{1}\right)\right\} \\
& +T_{q} \omega+K_{q} K_{b} \sin \left(\omega L_{1}\right) \ldots \ldots .
\end{aligned}
$$

新しいむだ時間補償器を付与した場合の安定限界を 式（6) から求める.ただし安定解析に用いたパラメー 夕は次式のように与えた。

$$
\begin{aligned}
& T_{q}=2.5, \quad K_{b}=1.0 / K_{q}, \quad L=L_{1} \\
& K_{m}=2.0, \quad T_{m}=0.1 \ldots \ldots \ldots \ldots \ldots \ldots \ldots \ldots \ldots \ldots
\end{aligned}
$$

結果を図 3 に示す。ここでPI 制御 $\left(T_{i}=1.0\right)$ につ いても同様の手法で安定限界を調べた。図 3 から PI 制御の場合と比較してむだ時間補償器を付与した場合 


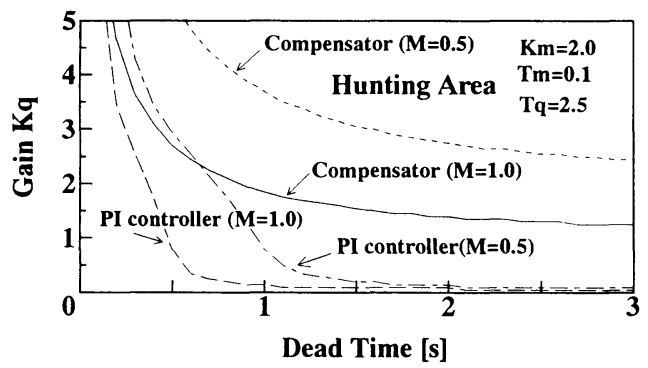

Fig. 3 Stability region

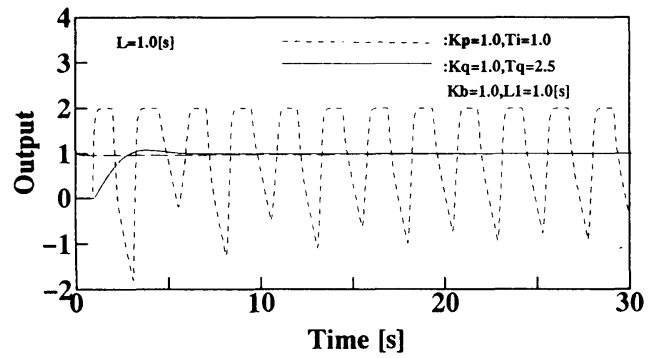

Fig. 4 Simulation

の安定領域は大きく拡大していることがわかる。また 非線形要素の線形係数 $M$ が大きくなるにつれて安定 領域が縮小する傾向にある. 図 4 にむだ時間を $L=$ $L_{1}=1.0 \mathrm{~s}$ とした場合の動特性の一例を示す。実線が むだ時間補償器を付与した場合, 点線が PI 制御器 (ゲ イン $K_{p}=1.0$, 積分時間 $\left.T_{i}=1.0\right)$ の場合である. $L=$ $1.0 \mathrm{~s}$ は空気圧管路では約 $200 \mathrm{~m}$ (内径 $6.0 \times 10^{-3} \mathrm{~m}$, 入 力圧 $0.1 \mathrm{MPa}$ ）に相当し, 実用上この值以上のむだ時 間を考えにくく，むだ時間補償という観点から十分で あると考えた。図 4 から PI 制御の場合，系は周期 2.4 $\mathrm{s}$ の発振現象を生じ安定な制御特性を得られないが, 補償器を付与した場合, 定常偏差のない安定な制御特 性が得られる(4).

$2 \cdot 3$ 周波数特性提案した補償器の有効性を周 波数特性を調べることにより明らかにする。ここで制 御対象を式 ( 2 ) とし, 用いるパラメー夕を以下のよう に設定した。

$$
\begin{array}{ll}
K_{p}=1.0, & T_{i}=1.0, \\
K_{q}=1.0, & T_{q}=2.5, \quad K_{b}=1.0, \quad L=L_{1}=1.0 \mathrm{~s}, \\
K_{m}=2.0, & T_{m}=0.1, \quad M=1.0 \quad \cdots \cdots \cdots \cdots \cdots(9)
\end{array}
$$

図 1 の制御系における一巡伝達関数の周波数特性を 図 $5 ， 6$ に示す。実線が新しいむだ時間補償器を用い た場合, 破線が PI 制御器を用いた場合の周波数特性 である. 図 5 より, 新しいむだ時間補償器を付与した 場合，低周波領域においてゲインの傾きがー $20 \mathrm{db} / \mathrm{dc}$

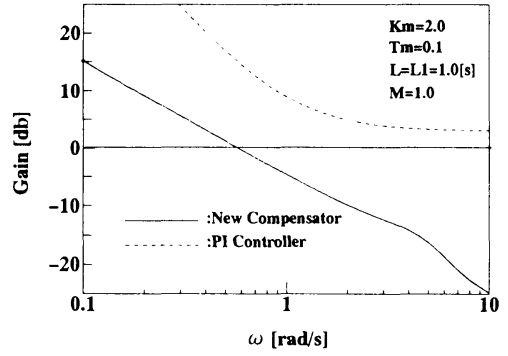

Fig. 5 Gain diagram

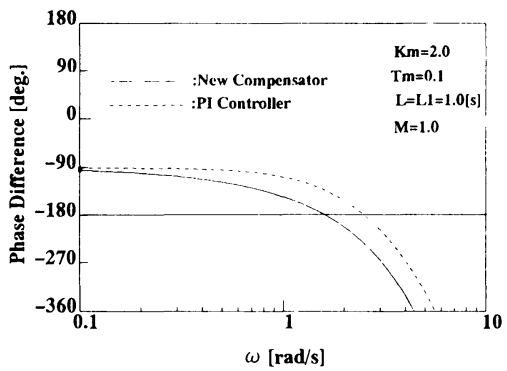

Fig. 6 Phase diagram

と大きく，周波数が $0 \mathrm{rad} / \mathrm{s}$ 付近ではゲインを大きく とれるため, 目標追従特性, 外乱除去特性, 低感度化 を図り，かつ定常偏差を零にすることができる．さら に高周波領域ではゲインを低く抑えて安定性を確保 し, 非振動の条件を満足しようとしていることがわか る.特にむだ時間系において $L$ が大きい場合、低周 波領域でも位相の遅れが大きくなるために, 開ループ の伝達関数のゲインを低周波領域のうちから 1 以下 $(0$ db) に抑えておく必要があり, 図 5 から本補償器を用 いた場合の一巡伝達関数のゲイン特性は $\omega \geqq 0.6$ で 0 $\mathrm{db}$ 以下 (1 以下) となっており, これを満足している. また図 6 から PI 制御と比較して位相遅れが認められ るが, 制御仕椂が要求する周波数帯域ではこれ以上の 遅れはないものと考えられ，制御系の設計に際し図 5 とあわせて十分なゲイン余裕をとることができる，新 しいむだ時間補償器を用いた場合, ゲイン余裕が 8.33 $\mathrm{db}$ ，位相余裕が $58.13 \mathrm{deg}$. となり，プロセス制御の設 計仕様を満足することができる.

\section{3. 無定位性プロセスの安定化}

提案したむだ時間補償器が定位性プロセスにおいて 有効であることは理論的, 実験的に確認してい る(4)(11).しかし無定位相プロセスに対し，本むだ時間 補償器の有効性は論じられていない。ここでは無定位 性プロセスに対して, 本むだ時間補償器の有効性を検 


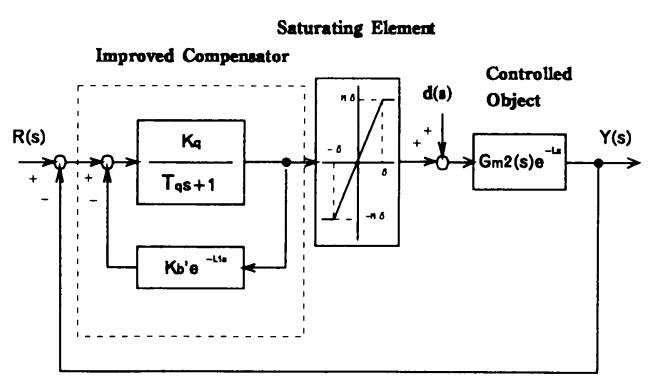

Fig. 7 Block diagram with improved time-delay compensator

証する. 式 ( 1 )で表現されるむだ時間補償器を無定位 性プロセスに付与した場合, その安定領域は P 制御の みの場合と比較して縮小傾向にあり, 定位性プロセス で有効であった式（１）のむだ時間補償器のパラメー夕 変更を行い, 無定位性プロセスに対しても, 有効であ ることを示す。

$3 \cdot 1$ パラメータ変更によるむだ時間補償器の改良

図 7 に改良したむだ時間補償器を付与した飽和形非 線形むだ時間システムのブロック線図を示す。ここで 制御対象の伝達関数 $G_{m 2}(s)$ を次式で表現する.

$$
G_{m 2}(s)=\frac{K_{m}}{s\left(T_{m} s+1\right)}
$$

式( 1 ) で示される従来のむだ時間補償器は, 正の局所 フィードバックループによって構成されているが, こ こでは負の局所フィードバックループによって補償器 を構成する.ただし補償器の構成要素は従来の補償器 と変わらないため, フィードバックゲイン $K_{b}$ を負に 設定すれば基本的な変更をすることなく補償器を改良 できる. 次式に改良したむだ時間補償器の伝達関数を 示す.

$$
\begin{gathered}
D_{2}(s)=\frac{K_{q}}{1+T_{q} s+K_{q} K_{b}{ }^{\prime} e^{-1_{1} s}} \\
\left(\text { ただし } K_{b}{ }^{\prime}=-K_{b}\right) \cdots \cdots \cdots \cdots
\end{gathered}
$$

パラメータの変更により改良したむだ時間補償器の 有効性を調べるため, ベクトル軌跡による安定解析を 行う. 解析結果の一例を図 8 に示す。ただし制御対象 のパラメータを次式とする.

$$
K_{m}=2.0, \quad T_{m}=0.1, \quad M=1.0, \quad L=L_{1}=1.0 \mathrm{~s}
$$

実線が改良したむだ時間補償器を含む系, 点線が従 来のむだ時間補償器を含む系のベクトル軌跡である. 図 8 より従来の補償器によるべクトル軌跡は飽和形非 線形要素の振幅軌跡 $-1 / N(z)$ と安定な交点をもち, この点でリミットサイクルを生じていることがわか

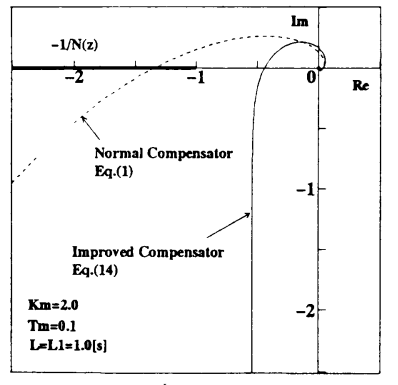

Fig. 8 Stability analysis based on Nyquist method

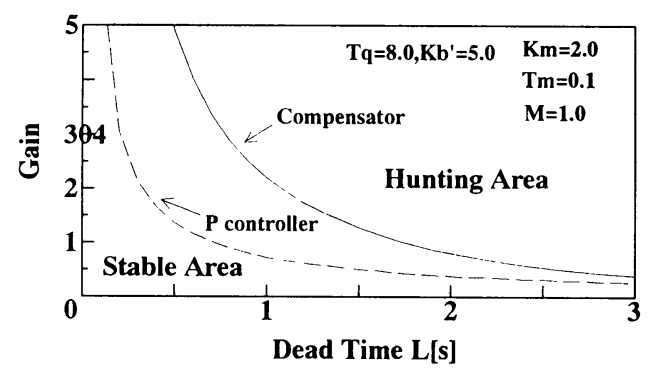

Fig. 9 Stability region

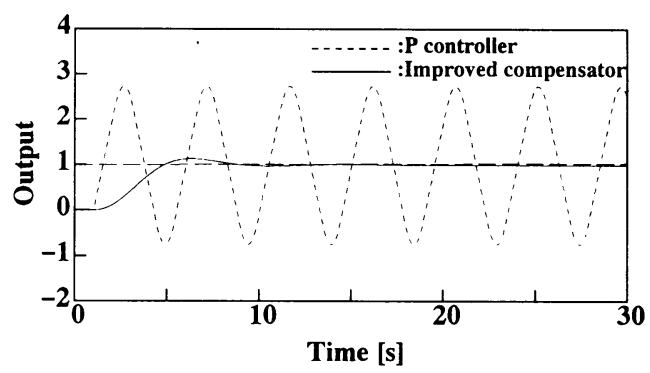

Fig. 10 Simulation

る. 一方, 改良した補償器のベクトル軌跡は振幅軌跡 と交点をもたず漸近安定となっている。このことから 改良したむだ時間補償器により発振現象を回避するこ とができると考えられる. また比例制御との安定領域 を比較しその有効性を図 9 に示す.またシミュレーシ ヨンによる動特性の一例を図 10 に示す.

$3 \cdot 2$ 動特性実験 式(11)のむだ時間補償器の付 与により動特性の改善が図られているかどうかを検証 するため, 無定位系における過渡特性のシミュレーシ ヨンを行った。ただしシミュレーションに用いるパラ メータを以下のように設定した.

$$
\begin{aligned}
& K_{p}=1.0, \\
& K_{q}=1.0, \quad T_{q}=8.0, \quad K_{b}{ }^{\prime}=5.0, \quad L=L_{1}=1.0 \mathrm{~s}, \\
& K_{m}=2.0, \quad T_{m}=0.1, \quad M=1.0 \quad \cdots \cdots \cdots \cdots \cdots \cdots \cdots \cdots \cdots(13)
\end{aligned}
$$

実験結果の一例を図 10 に示す.実線が改良したむ 


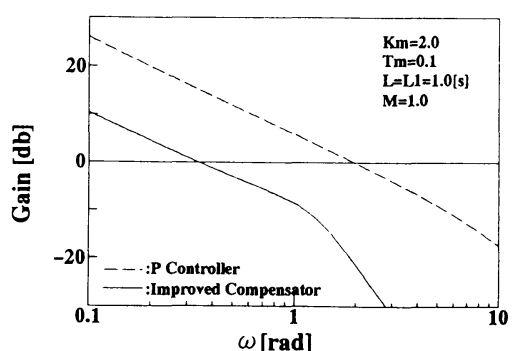

Fig. 11 Gain diagram

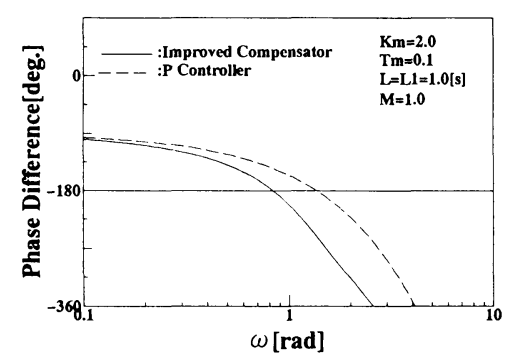

Fig. 12 Phase diagram

だ時間補償器を付与した場合, 点線が $P$ 制御の結果 である。 $P$ 制御の場合, 発振現象を生じ, 安定な制御 特性を得られていない. しかしむだ時間補償器を付与 した場合出力値は約 $7.8 \mathrm{~s}$ で定常状態に達し, 定常偏 差のない良好な制御特性を得ることができた。

$3 \cdot 3$ 周波数応答特性 定位系の場合と同様に, 無定位系における一巡伝達関数の周波数応答を調べた 結果を図 11,12 に示す。ここで用いるパラメータは 式(13)のように設定した.

図 11, 12 より補償器が高周波数額域でゲインを低 く抑えているためにロバスト安定性に対して有利であ ると言える.

\section{4. 根軌跡による動特性解析}

制御系の過渡応答特性は, 閉ループ伝達関数の極の 配置と目標出力の形により定まる. 閉ループ伝達関数 の極が与えられていれば, 制御出力の各モードの大き さが決まり, 応答の評価が可能になる。しかし, 新し いむだ時間補償器を含む系は次式のように状態にむだ 時間を含むことから一般に無限個の極をもつ。

$$
\begin{aligned}
& x(t)=A x(t)+B x\left(t-L_{1}\right)+C x(t-L) \\
& \quad+D r(t-L) \\
& y(t)=E x(t) \\
& A, B, C \in R^{2 \times 2}, \quad D \in R^{2 \times 1}, \quad E \in R^{1 \times 2}
\end{aligned}
$$

よって連続系に扔いてはP Pade の近似手法等を適用せ
Saturating Element

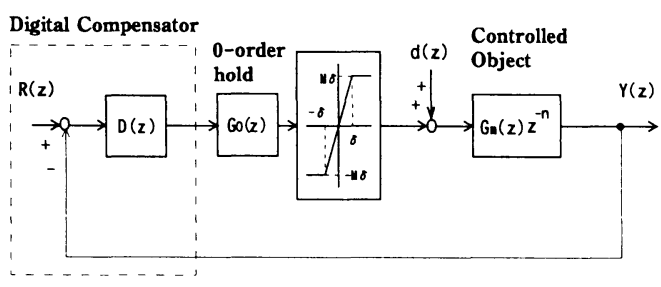

Fig. 13 Block diagram of discrete system

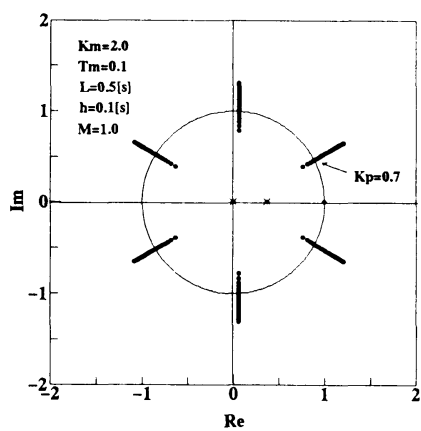

Fig. 14 Root locus with P controller

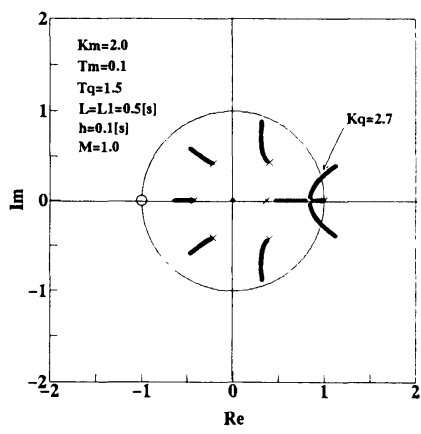

Fig. 15 Root locus with new compensator

ずに極および根軌跡による動特性解析を行うことは困 難である．本章ではむだ時間補償器の定性的な検討を 行うため, 系を離散化し $z$ 平面による極およびその特 性根の位置から補償器のはん化性を調べる。さらに上 述の結果を基に根軌跡による定性的検討を行い,むだ 時間補償器を含む制御系の動的挙動を考察する.

$4 \cdot 1$ 定位系の根軌跡 図 13 亿離散系のブロック 線図を示す. 図 13 においてディジタル補償器のパル ス伝達数を $D(z)$ とする. 制御対象を 0 形とすると, 制御対象のパルス层達関数は 0 次ホルダおよび式 (2) の伝達関数より式(15)のようになる.

$$
G_{m}(z) z^{-n} \triangleq G_{m 1}^{\prime}(z)=K_{m} \frac{1-p}{z-p} z^{-n}
$$




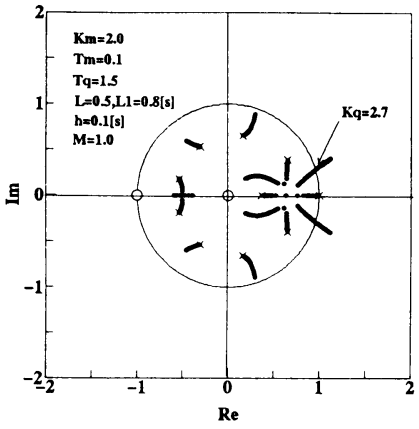

Fig. 16 Robust stability analysis by root locus $(\Delta L=-0.3)$

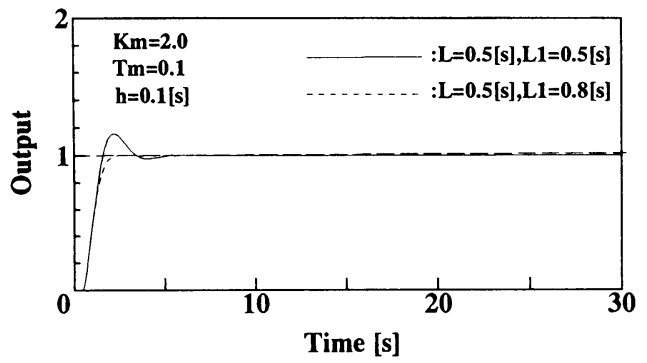

Fig. 17 Robustness of response $(\Delta L=-0.3)$

ただし $p=e^{-h / T m}, L=n \cdot h, h$ はサンプリング周期 である。

離散時間特性方程式を DKA 法 ${ }^{(6)}$ を用いて数值計算す ることにより図 13 の系における動的挙動を根軌跡に より解析する。ここで制御対象のパラメータを次式と し，むだ時間を $L=L_{1}=0.5 \mathrm{~s}$ とする.

$$
\begin{aligned}
& T_{q}=1.5, \quad K_{b}=1.0 / K_{q}, \quad K_{m}=2.0, \\
& T_{m}=0.1, \quad M=1.0 \quad \ldots \ldots \ldots \ldots \ldots \ldots \ldots \ldots \ldots \ldots \ldots
\end{aligned}
$$

図 14 に $P$ 制御における根軌跡, 図 15 にむだ時間 補償器を考慮した場合の根軌跡を示す。ここで○印が 零点， ×印が極である，z平面における安定化条件は， パルス伝達関数の極および根が単位円内に存在するこ とと同値である.

図 14 より, $P$ 制御の場合, 制御器のゲインが $K_{p} \geqq$ 0.7 と多少増加するだけで根は単位円外に発散し, 不 安定システムとなる。しかし図 15 より新しいむだ時 間補償器を付与した場合, 安定限界に達する補償器の ゲイン幅が $K_{q} \leqq 2.7$ と $P$ 制御に比べて大きくするこ とができる。

次に補償器におけるむだ時間の同定は一般に困難で あり，そのパラメータは変化しやすい.このためむだ 時間システムでは，むだ時間の同定誤差に対するロバ スト性が要求される。そこでむだ時間の同定誤差が生

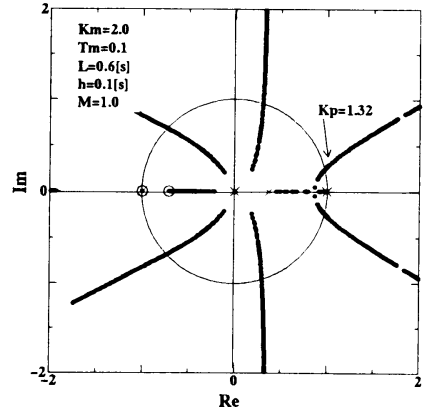

Fig. 18 Root locus with $\mathrm{P}$ controller

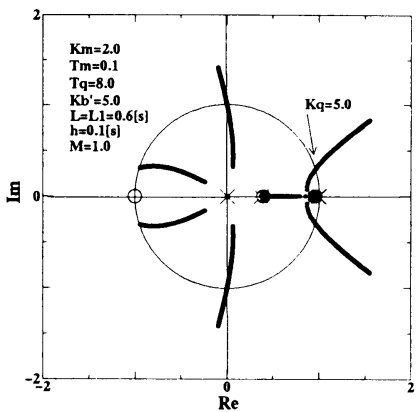

Fig. 19 Root locus with new compensator

じた場合の根軌跡と過渡応答を調べる，むだ時間を $L=0.5 \mathrm{~s}$ とし, 補償器のむだ時間を $L_{1}=0.8 \mathrm{~s}$ とした 場合の根軌跡を図 16 に, 過渡応答を図 17 に示す。

図 16 より, むだ時間の同定誤差 $(\Delta L=-0.3)$ が生 じた場合に扔いてもゲインの調整範囲を広く設計する ことができ，系を安定化することができる．またゲイ ンが大きくなるにつれて単位円の外に根が移動するだ けでなく実軸もしくは原点に向かって移動する根が存 在し, ゲインが大きいときに対しても系を安定化させ る要因の一つとなっていると推察できる. 図 17 から むだ時間の同定誤差が生じても，良好な応答が得られ ていることがわかる.

$4 \cdot 2$ 無定位系の根軌跡 $4 \cdot 1$ 節と同様にして無 定位系の根軌跡を調べる。図 13 における制御対象の パルス伝達関数は零次ホルダおよび式 (10)の伝達関数 より次式となる.

$$
\begin{aligned}
& G_{m}(z) z^{-n} \triangleq G_{m 2}{ }^{\prime}(z) \\
& \quad=K_{m} \frac{\left(h-T_{m}+T_{m} p\right) z+T_{m}-T_{m} p-p h}{(z-1)(z-p)} z^{-n}
\end{aligned}
$$

ただし $p=e^{-h / T m}, L=n \cdot h$ である.

定位系の場合と同様の手法で, 無定位系の場合の動的 挙動を根軌跡により解析する。ここで制御対象のパラ 


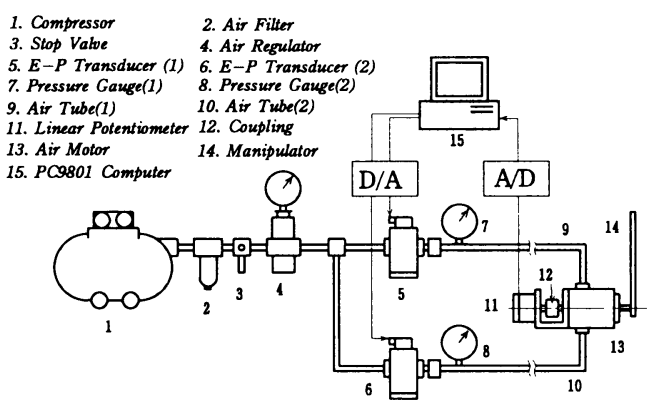

Fig. 20 Structure of experimental equipment

メータを次式とし，むだ時間を $L=L_{1}=0.6 \mathrm{~s}$ とする. $T_{q}=8.0, \quad K_{b}{ }^{\prime}=5.0, \quad K_{m}=2.0$,

$T_{m}=0.1, \quad M=1.0$

図 18 に P制御における根軌跡, 図 19 にむだ時間補 償器を考慮した場合の根軌跡を示す，応答に最も影響 を与える代表根，(1,0)近傍の根の動きを見ると, 図 19 の補償器を使用したほうが, 代表根の軌跡が広が り，根が単位円外に出るときのゲインも $K_{q}=5.0$ とな り, 図 18 の場合の $K_{p}=1.32$ に比べて, ゲインの安定 範囲を広げている。このため $\mathrm{P}$ 制御よりゲインの選 択の幅を広げて設計できる.

\section{5. 空気圧ロボットへの適用}

無定位系に対し, 式(11)で表される改良した補償器 の有効性を確かめるため, 空気圧モー夕を用いた 1 リ ンク空気圧ロボットを用いて実験を行った。図 $20 に$ 空気圧ロボットの実験装置概略図を示す(7).

ここで空気圧管路は一次遅れ伝達関数 $G_{L}(s)$ とむ だ時間 $e^{-L s}$ で表され, 空気圧ロボット $G_{m}(s)$ は I 形 の系で表現される(8).この場合, 防爆性の観点から空 気圧駆動部と電空変換部を長い空気圧管路で結ぶもの とする.このような空気圧ロボットは無定位系プロセ スであり, 空気圧管路が長くなると，信号遅れ（むだ時 間)により発振現象が生じ安定な動作が行えない。そ こで本補償器を適用し, 安定な制御動作を行わせる。 ここでは空気圧管路の長さは $40 \mathrm{~m}$ とした。この場合, むだ時間は実験により $L=0.12 \mathrm{~s}$ となる(4). したがっ て, 式(11)で表される補償器のパラメー夕は次のよう に決定した。

$$
\begin{aligned}
K_{p} & =0.2, \quad T_{1}=10.0, \\
K_{q} & =1.2, \quad T_{q}=20.0, \quad K_{b}{ }^{\prime}=2.5, \\
K_{v} & =9.72, \quad L_{1}=0.12 \quad \ldots \ldots \ldots \ldots \ldots \ldots . . .
\end{aligned}
$$

図 20 の空気圧ロボットによる実験結果の一例を図 21 に示す.マニピュレータの目標角度は $20 \mathrm{deg}$.およ

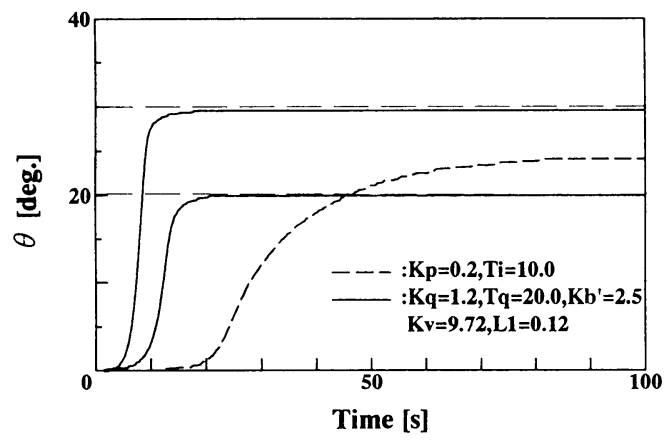

Fig. 21 Experimental result

び $30 \mathrm{deg}$. に設定した. 実線が補償器を用いた場合, 点線が目標角度 $20 \mathrm{deg}$. とした場合の PI 制御器によ る過渡応答特性の一例である。

図 21 に示すようにPI 制御器を用いた場合立上が りが遅く,オーバシュートが大きいため制定時間が長 くなる.またゲインを上げた場合発振現象が生じ, 安 定な制御特性が得られない.これに対して本補償器を 用いた場合，過渡特性に関し良好な応答が得られてい る. 以上の結果より, 本補償器は無定位系の実システ ムへの安定化に対しても有効であることを示した。

\section{6. 結言}

本研究は非線形むだ時間システムに対して生する発 振現象を防止するための安定化法として, 新しいむだ 時間補償法を提案し, その有効性をシミュレーション と実験により確認したもので, 次の結果が得られた。

（1）本研究で提案したむだ時間補償器のはん化性 を調べるため，0 形で表される一般的な非線形むだ時 間システムを構成し，むだ時間の同定誤差が生じた場 合の許容誤差範囲を示した。

（2）制御対象が I 形とむだ時間で表現できる系に おいても補償器のパラメー夕を調整することで, 定常 偏差のない良好な応答特性が得られることを確認し た。

（３） システムの定性的な検討を行うため, 系を離 散化し， $z$ 平面による極および特性根の配置からむだ 時間補償器を付与した系の安定限界ゲインと動的挙動 を調べた。

（4）本補償器をI 形十むだ時間で表される空気圧 ロボットに適用し, 実験により本法の有効性を確認し た。

以上の解析結果から, 非線形むだ時間システムとし て表される制御系の安定化に関し，実用性のある有効 な安定化手法を示した。 


\section{文献}

(1) Smith, O. J. M., A Controller to Overcome Dead time, ISA J., 6-2 (1959), 28-33.

(2) 朝倉俊行・ほか 2 名, 電空弁ポジショナにおける発振現 象の防止.とロバスト安定性, 機論, 57-541，C (1991)，8288.

（3）朝倉俊行・ほか 3 名, 非線形性を考慮した電空弁ポジシ ヨナの発振現象の解析, 電子情報通信学会研究報告, NLP89-82, 84-460, (1990), 1-9.

(4) 徐彬・朝倉俊行・ほか 3 名, 防爆式電空弁ポジショナの 安定化と実験的検討, 機論, 60-578, C (1994), 111-119.

（5）計測自動学会編，自動制御ハンドブック基礎編，(1983）, 283-284, オーム社.
（6）石田義久, デジタル制御のポイント, (1990)，86-93，産業 図書.

（7）朝倉俊行・ほか 4 名, 防爆式空気圧ロボットの動特性解 析，北信越支部第 31 期総会講演会論文集，947-01 (1994)， 102-104.

（8）香川利治・ほか 3 名, 空気圧管路の動特性を表示する低 次元モデルに関する研究, 計測自動制御学会論文集, 21-9 (1985), 67-72.

（9）長谷川健介, 基礎制御理論 II, (1987)，131-133, 昭晃堂.

(10) Palmor, Z., Stability properties of Smith dead-time compensator controllers, Int, J, Control, 32-6 (1980) 937-945.

（11）徐彬・朝倉俊行・ほか 2 名, 飽和型非線形特性をもつむ だ時間システムディジタル制御とロバスト安定性, 機論, 59-564, C (1993), 237-243. 